\title{
PENGHAKIMAN BERDASARKAN PERBUATAN \\ DI ROMA 2:1-16
}

\section{Fabio Valentino*}

\begin{abstract}
Abstrak: Tema "Penghakiman berdasarkan perbuatan" yang muncul di Roma 2:1-16 telah menimbulkan berbagai perbedaan pandangan di kalangan para ahli. Perdebatan ini disebabkan tema "Penghakiman Berdasarkan Perbuatan" seolah-olah bertentangan dengan pernyataan Paulus mengenai "Pembenaran oleh iman" dan perbuatan dapat menjadi penentu keselamatan. Tulisan ini berusaha memberikan sumbangsih untuk memahami "Pembenaran oleh iman" melalui kerangka soteriologi Paulus.
\end{abstract}

Abstract: The theme of "Judgment according to Works" that appears in Romans 2: 1-16 has given rise to different views among experts. This debate is caused by the theme " Judgment according to Works " as if it contradicts with Paul's statement about "Justification by faith" and works can be determinants of salvation. This paper attempts to contribute to understanding this theme through Paul's soteriological framework.

Kata-kata Kunci: penghakiman berdasarkan perbuatan, penghukuman, perbuatan, Taurat, keselamatan.

\section{Pendahuluan}

Tema "Penghakiman berdasarkan perbuatan" di Roma 2:1-16 hingga kini belum disepakati bagaimana cara menafsirkannya. ${ }^{1}$ Salah

* Penulis adalah alumni program M.Th. Sekolah Tinggi Teologi Amanat Agung. Penulis dapat dihubungi melalui email: fbvaltinos@gmail.com.

1. Tema mengenai "Penghakiman berdasarkan perbuatan" juga muncul di beberapa tulisan Paulus lainnya (Rm. 8:13; 14:10-12; 1Kor. 3:10-15; 2 
satu penyebabnya adalah pernyataan Paulus "la akan membalas setiap orang menurut perbuatannya" di ayat 6 dan "Karena bukanlah orang yang mendengar hukum Taurat yang benar di hadapan Allah, tetapi orang yang melakukan hukum Tauratlah yang akan dibenarkan" di ayat 13. ${ }^{2}$ Kedua klausa ini mengesankan bahwa perbuatanlah (bukan iman) yang menjadi penentu seseorang untuk diselamatkan di pengadilan akhir zaman. Pernyataan ini seakan bertolak belakang dengan ajaran Paulus di Roma 3:20-28 yang menekankan bahwa tidak ada seorang pun dibenarkan karena perbuatan melainkan oleh iman. Michael Bird menganggap hal ini sebagai crux interpretum atau "jungle full of traps and temptations." ${ }^{3}$ Begitu juga dengan N. T. Wright yang memberikan komentar tentang kesulitan di dalam menafsir Roma 2:1-16, sebagai berikut:

Roma 2 is joker in the pack. Standard treatments of Paul and the Law have often failed to give it the prominence that one might expect it to have, judging by its position within his most-discussed letter. But generations of eager exegetes, anxious to get to the juicy discussions that surround 3.19-20, 3.21-31, and so on, have hurried by Romans 2, much as tourists on their way to Edinburgh hurry through Northern England, unaware of its treasures. ${ }^{4}$

Kor. 5:10; 9:6; 11:5; Gal. 6:7-8; Kol. 3:25; Ef. 2:10; 6:8; 1 Tim. 5:24-25; 2 Tim. $4: 14)$.

2. Thomas R. Schreiner, The Law and Its Fulfillment: A Pauline Theology of Law (Baker: Grand Rapids, 1993), 179.

3. Michael Bird, The Saving Righteousness of God: Studies on Paul, Justification, and the New Perspective (Eugene: Wipf \& Stock, 2007), 172.

4. N. T. Wright, "The Law in Romans 2," dalam Paul and the Mosaic Law, ed. James D. G. Dunn (Tübingen: Mohr, 1996), 131. 
Permasalahan eksegesis Roma 2:1-16 sebagaimana yang diungkapkan di atas telah mendapat respons dari para ahli Perjanjian Baru. Secara garis besar ada tiga pandangan yang menonjol, yaitu pertama menyatakan "Penghakiman Berdasarkan Perbuatan" inkonsisten. Salah satu tokohnya adalah E. P. Sanders. la menilai Paulus tidak konsisten dengan ajarannya sendiri. ${ }^{5}$ Sanders berpandangan bahwa Yudaisme Bait Allah Kedua sangat menekankan anugerah Tuhan. ${ }^{6}$ Mengenai penghakiman berdasarkan perbuatan Sanders berpandangan bahwa perbuatan bukanlah menjadi dasar untuk mendapatkan jaminan keselamatan melainkan perbuatan hanyalah supaya umat tetap di dalam perjanjian Tuhan. ${ }^{7}$ Atau dengan kata lain, perbuatan baik dapat menjadi penentu keselamatan. Hal ini secara tidak langsung bertentangan dengan pemikiran Paulus mengenai keselamatan oleh karena iman (Rm. 3:9, 20). ${ }^{8}$

Pandangan kedua "Penghakiman Berdasarkan Perbuatan" merupakan hipotesis. Pandangan ini diwakili oleh Douglas Moo. la berpendapat kepastian keselamatan bagi yang melakukan kebaikan, tetapi kekuatan dosa menghambat seseorang untuk berbuat baik sehingga membutuhkan keselamatan. ${ }^{9}$ Oleh karena itu, semua orang

5. E. P. Sanders, Paul, The Law, and The Jewish People (Minneapolis: Fortress, 1983), 123-36.

6. E. P. Sanders, Paul and Palestinian Judaism: a Comparison of Patterns of Religion (Minneapolis: Fortress, 1977), 421-22.

7. Sanders, Paul and Palestinian Judaism, 517.

8. Sanders, Paul, The Law, and The Jewish People, 123-24.

9. Douglas Moo, The Epistle to the Romans, NICNT (Grand Rapids: Eerdmans, 1996), 142. 
akan dihakimi berdasarkan perbuatan. Moo berpendapat, "Paul's purpose in 2:6-11 is to establish the principle that God will judge every person on the same basis - by works, not by religious heritage or national identity. Paul's focus is on the standard of judgment." ${ }^{10}$

Pandangan ketiga menyatakan Paulus memang mengajarkan "Penghakiman berdasarkan perbuatan" di Roma 2:1-16. Setidaknya pandangan ini diwakili oleh N. T. Wright dan Thomas Schreiner. Menurut Wright, Roma 2:1-16 adalah suatu kecaman Paulus terhadap orang Yahudi yang menekankan bahwa semua orang akan dihakimi berdasarkan perbuatan oleh Tuhan, tanpa terkecuali. ${ }^{11}$ Perbuatan yang dimaksudkan oleh Wright adalah perbuatan mewakili keseluruhan hidup seseorang termasuk iman percaya kepada Tuhan. ${ }^{12}$ Pembenaran melalui ketaatan kepada Taurat di Roma 2:13 dapat terjadi karena tujuan Taurat telah tergenapi di dalam Kristus, maka setiap orang yang percaya kepada Kristus telah melakukan hukum Taurat. ${ }^{13}$ Dalam hal ini, penyertaan dan karya Roh Kudus memampukan orang untuk melakukan perbuatan baik sampai di pengadilan akhir. ${ }^{14}$ Sedangkan menurut Schreiner, Roma 2:6-10 adalah untuk orang Yahudi. Hal ini berhubungan dengan ayat 5 yang berbicara mengenai "menimbun murka" pada waktu eskatologi penghakiman akhir. Walaupun Schreiner mengakui bahwa "Penghakiman berdasarkan perbuatan" memang lazim di masa

10. Moo, The Epistle to the Romans, 142.

11. Wright, "The Law in Romans 2," 148.

12. N. T. Wright, "The New Perspective on Paul (2003)" dalam Pauline Perspective: Essays on Paul, 1978-2013 (Minneapolis: Fortress, 2013), 281.

13. Tom Wright, What St. Paul Really Said (Oxford: Lion, 1997), 126-27.

14. N. T. Wright, Paul: Fresh Perspectives (London: SPCK, 2005), 148. 
Yudaisme Bait Allah Kedua namun ia tidak melihat bahwa perbuatan menjadi penentu di pengadilan akhir. ${ }^{15}$ Pembalasan berdasarkan perbuatan hanya berlaku bagi yang melakukan kejahatan. Sementara bagi yang percaya kepada Kristus, perbuatan adalah sebagai bukti iman dan di pengadilan akhir akan dibenarkan. ${ }^{16}$

Penjabaran di atas memperlihatkan bahwa para ahli belum memiliki kesepakatan untuk memahami ajaran "Penghakiman berdasarkan perbuatan" di Roma 2:1-16. Isu ini semakin rumit karena dibingkai di dalam kerangka soteriologi Paulus. Tujuan tulisan ini adalah memahami konsep "Penghakiman berdasarkan perbuatan" di Roma 2:1-16 yang seolah-olah membuka jalan kepada pembenaran berdasarkan perbuatan di penghakiman akhir dan secara tidak langsung kontradiktif dengan pemikiran Paulus mengenai pembenaran berdasarkan iman.

\section{Persamaan Kedudukan dan Murka Tuhan}

Paulus mengkritik orang Yahudi yang merasa memiliki status istimewa sehingga dapat terhindar dari penghakiman. ${ }^{17}$ Hal ini

15. Schreiner, The Law \& Its Fulfillment, 191.

16. Schreiner, The Law \& Its Fulfillment, 203.

17. Penggunaan "simple verb" kata kpíveıv "menghakimi" dalam surat Roma ditemukan sekitar delapan belas kali $(2: 1$ (3x), 3, 12, 16, 27; 3:4, 6, 7; 14:3, 4, 5 (2x), 10, 13 (2x), 22) dengan pemakaian terbanyak di Roma 2 sebanyak tujuh kali dan Roma 14 sebanyak delapan kali. Sementara penggunaan kata крí $\alpha \alpha$ "penghakiman" sebanyak enam kali $(2: 2,3$; 3:8; 5:16; 11:33; 13:7). Kemudian penggunaan "menghukum" sebanyak empat kali $(2: 1 ; 8: 3,34 ; 14: 23)$ dan

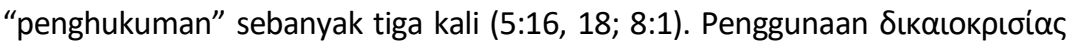
"hukuman Allah" hanya ditemukan di Roma 2:5. Kent L. Yinger, Judgment 
ditekankan Paulus di Roma 1-5. Kata penghubung (Rm. 2:1) dı́, menunjukkan Roma 1:18-32 masih berhubungan dengan Roma 2:1-

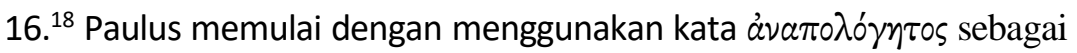
persamaan kedudukan manusia di penghakiman Allah. ${ }^{19}$ Frasa ä $\theta \rho \omega \pi \varepsilon$

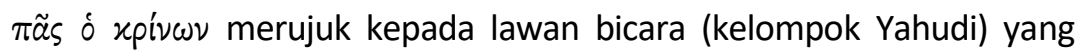
mengklaim dapat terluput dari penghakiman Allah karena status

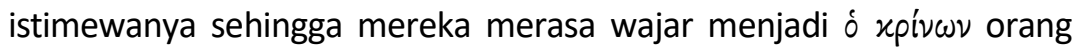

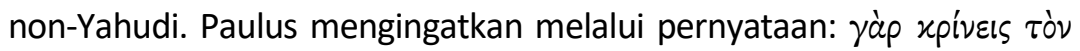

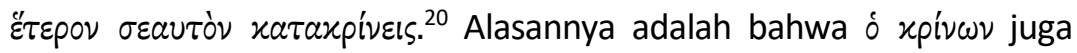
melakukan dosa yang sama dengan yang dinyatakan di dalam Roma

According to Deeds, Society for New Testament Studies 105. (Cambridge: Cambridge University, 1999), 143.

18. Ada beberapa pendapat mengenai kata penghubung $\delta$ ıó apakah masih berhubungan dengan Roma 1:18-32. Frederic Louis Godet (Commentary of Romans [Grand Rapids: Kregel, 1984], 114) berpendapat bahwa kata סı́, hanya untuk menghubungkan Roma 1:32 saja karena ide dari melakukan "halhal demikian" sama di Roma 2:1. John Murray (The Epistle to the Romans [Grand Rapids: Eerdmans, 1965], 56) berpendapat kata Sió, merupakan silogisme Paulus; Roma 2:1-16 adalah kesimpulan dari ide sebelumnya. Namun para ahli banyak yang berpendapat bahwa Roma 2:1-16 masih berhubungan dengan Roma 1:18-32 (James Dunn, Romans 1-8; C. E. B. Cranfield, A Critical and Exegetical Commentary on the Epistle to the Romans [New York: T\&T Clark International, 2004], 141; Moo, Romans, 124; Thomas R. Schreiner, Romans, BECNT [Gand Rapids: Baker Academic, 2003], 106).

19. A Greek-English Lexicon of the New Testament and Other Early Christian Literature, edisi ke 3, s. v. "ảvaro入ópntos, ov"

20. Francis Watson, Paul, Judaism, and the Gentiles (Grand Rapids: Eerdmans, 2007), 97. Bdk. Dunn, Romans 1-8 (Word Biblical Commentary vol. 38a. Nasville: Nelson, 1988), 80; Arland J Hultgren, Paul's Letter to the Romans: A Commentary (Grand Rapids: Eerdmans, 2011), 113. 
1:18-32. ${ }^{21}$ Dengan demikian, semua manusia sama di hadapan penghakiman Tuhan. Klaim ini didukung dengan argumentasi pada ayat

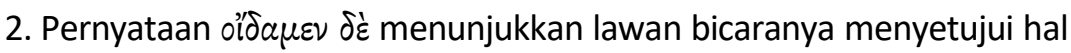

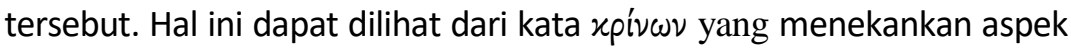
menjatuhkan hukuman kepada orang yang berbuat jahat.

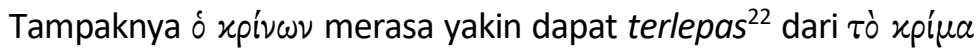
$\tau \circ \tilde{u} \Theta \varepsilon \circ$. $^{23}$ Paulus menolak pemikiran demikian. Pengulangan frase $\delta$

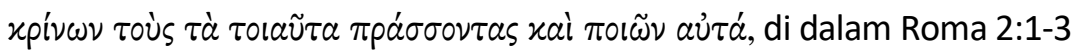
memiliki efek retorik, yaitu kemunafikan dan kefanatikan lawan bicaranya. ${ }^{24}$ Kata $\dot{x} x \phi \varepsilon v^{\prime} \xi_{n}$ dalam konteks ini menekankan kesamaan status antara orang Yahudi dan bangsa-bangsa kafir. Jadi setiap orang tanpa terkecuali akan dihakimi berdasarkan perbuatan.

Paulus mengingatkan ó xpívwv untuk memahami maksud kemurahan dan kesabaran Tuhan yang telah dilimpahkan kepada mereka. Di dalam perspektif Yudaisme, kemurahan ilahi berada di dalam

21. Dunn, Romans 1-8, 80.

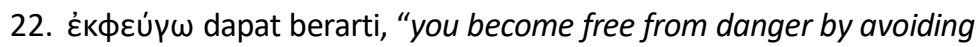
some peril." A Greek-English Lexicon of the New Testament and Other Early

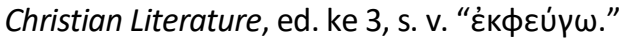

23. Joseph A. Fitzmyer, Romans: A New Translation with Introduction and Commentary (The Anchor Bible. New York: Doubleday, 1993), 300; W. Sanday and A. C. Headlam. A Critical and Exegetical Commentary on the Epistle to the Romans. International Critical Commentary (Edinburg: T\&T Clark, 1980), 55.

24. Robert Jewett, Romans: A Commentary, Hermeneia (Minneapolis: Fortress, 2007), 199. 
konteks relasi perjanjian antara $\mathrm{YHWH}$ dan manusia. ${ }^{25}$ Anugerah keselamatan hadir di dalam Perjanjian Tuhan, sehingga setiap umat Tuhan yang setia kepada Perjanjian-Nya akan mendapatkan keselamatan. ${ }^{26}$

Di ayat 5, Paulus menunjukkan hal sebaliknya. Kekerasan hati dan

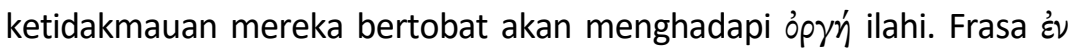

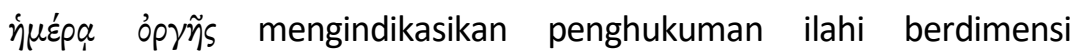
eskatologis. Moo menyebutnya, "quasi-technical biblical language for

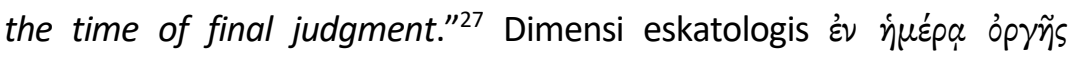

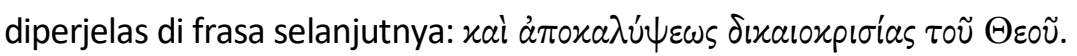
Kata penghubung kai, digunakan ketika penghukuman Allah yang adil

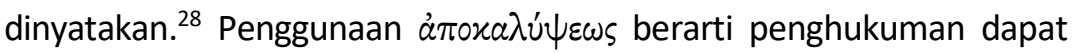
terjadi pada masa sekarang dan akan datang, tetapi pada bagian ini aspek eskatologis lebih ditekankan. ${ }^{29}$

\section{Penghukuman Berdasarkan Perbuatan}

25. A Greek-English Lexicon of the New Testament and Other Early Christian Literature, ed. ke-3, s. v. "крпбтós."

26. Dunn, Romans 1-8, 82.

27. Moo, Romans, 134. Konsep penghakiman ilahi yang berdimensi eskatologis juga muncul di dalam Perjanjian Lama (Am. 5:18; Yes. 2:12; 13:6; 24:21; Yer. 46:10; YI. 2:1; Zef. 1:7; Yeh. 7:7; 30:3; Zak. 14:1; Mal. 3:2; 4:1).

28. A Greek-English Lexicon of the New Testament and Other Early Christian Literature, ed. ke-3, s. v. "kai.."

29. Grandt R. Osborne, Romans (Illinois: InterVarsity, 2004), 62-64; Käsemann, Romans, 56. 
Paulus memaparkan konsep penghakiman berdasarkan perbuatan secara kiastik: ${ }^{30}$

A ay. 6: Pembalasan Tuhan berdasarkan perbuatan

B ay.7: berbuat baik-hidup kekal, kemuliaan, pengharapan dan ketidakbinasaan

$C$ ay. 8: Tidak taat - geram dan murka

$C^{\prime}$ ay. 9: berbuat jahat - penderitaan dan kesusahan

$B^{\prime}$ ay. 10: berbuat baik - kemuliaan, kehormatan dan damai sejahtera $A^{\prime}$ ay. 11: karena Allah tidak berpihak

Bentuk kiastik ini memperlihatkan bahwa Tuhan akan menghakimi setiap orang tanpa terkecuali berdasarkan perbuatan mereka. Tuhan akan menghukum orang yang berbuat jahat $\left(C^{-}-C^{\prime}\right)$. Perbuatan baik akan diganjar dengan keselamatan (B-B') dan B' mengindikasikan orang yang perbuatan baik akan terhindari dari penghukuman. ${ }^{31}$

Konsep penghakiman ilahi di akhir zaman dinyatakan pada baris A (ay. 6). Paulus memakai ayat Perjanjian Lama sebagai landasan teologis penghakiman berdasarkan perbuatan, karena ayat ini terinspirasi dari Mazmur 62:13 dan Amsal 24:12:

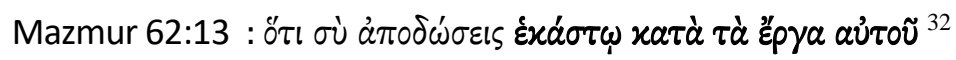

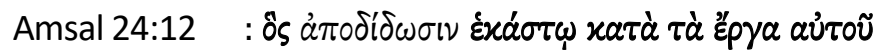

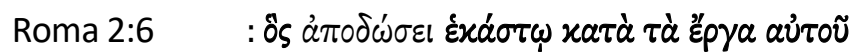

Para ahli Perjanjian Baru berbeda pendapat mengenai definisi pemakaian ayat Perjanjian Lama ini. Dunn menyebutnya, "direct

30. Yinger, Judgment According to Deeds, 153; Moo, Romans, 153.

31. Yinger, Judgment According to Deeds, 153. bdk. Moo, Romans, 153.

32. $L X X=61: 13$. 
quotation of an established principle of Jewish faith, with the formulation of Ps. 62:12 [LXX 61:13] and Prov. 24:12 at the forefront of Paul's mind." ${ }^{33}$ Ellis menyebutnya, "allusions to the Old testament.." ${ }^{34}$ Yinger berpendapat bahwa agak sulit untuk menentukan kutipan atau alusi di bagian mana yang dipakai oleh Paulus, apakah Perjanjian Lama atau Yudaisme, karena ungkapan ini telah menjadi pandangan umum di masa Bait Allah Kedua. ${ }^{35}$ Paulus mengutip secara tidak langsung Mazmur 62:13 dan Amsal 24:12 untuk mendukung argumentasinya tentang

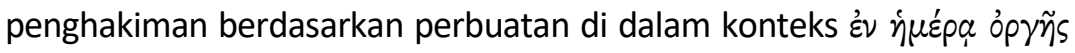
(ayat 5). ${ }^{36}$

Pemakaian preposisi kata, perlu disoroti. Menurut Yinger, kata, sebagai "evidential basis" dan bukan "instrumentality," yaitu menekankan hasil dari perbuatan. ${ }^{37}$ Sedikit berbeda dengan Yinger,

33. Dunn, Romans 1-8, 87.

34. Edward Earle Ellis, Paul's Use of the Old Testament (London: Oliver and Boyd, 1957), 153.

35. Yinger, Judgment According to Deeds, 157.

36. Jonathan A. Linebaugh, God, Grace, and Righteousness in Wisdom of Solomon and Paul's Letter to the Romans (Boston: Brill, 2013), 129-30.

37. Pandangan ini mendapat kritik dari Chris VanLandingham (Judgment \& Justification in Early Judaism and the Apostle Paul [Peabody: Hendrickson, 2006], 220-21), "... Yinger misrepresents the article of C. H. Cosgrove form whom he derives his data concerning the preposition katà. In, his article, Cosgrove analyzes what the Greek prepositions mean when used with $\delta$ เкаı $\omega$. Cosgrove admits this distinction between instrumentality and evidential basis may be artificial in most contexts, but not in Paul. What he means by 'in Paul' is the

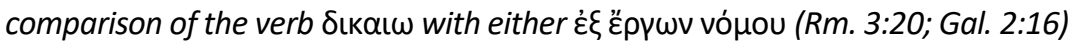
or (e.g. Rm. 3:22, 26). Cosgrove does not discuss the basic meaning of Katà., even in a judicial context. Cosgrove, moreover, does not discuss Romans 2 or

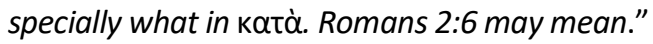


VanLandingham berpendapat $\varkappa a \tau \grave{\alpha}$, sebagai realitas batin ("inner reality") yang muncul dari perbuatan. ${ }^{38}$ Menurut penulis, baik Yinger maupun VanLandingham, keduanya berkesinambungan karena pembalasan Tuhan dapat dilihat dari dua sisi, yaitu dari realitas batin dan hasil perbuatan. Bentuk indicative future à $\pi \delta \delta \dot{\sigma} \sigma \varepsilon l$ mengindikasikan penghukuman Tuhan akan dilakukan di masa yang akan datang. ${ }^{39}$ Penghakiman tersebut berlaku bagi setiap orang. ${ }^{40}$

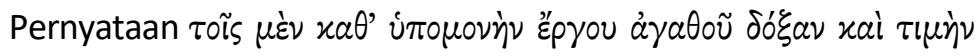

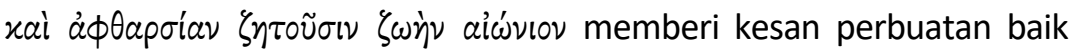
menjadi penentu seseorang mendapatkan kehidupan kekal. Ada dua kata yang penting di ayat ini, yaitu $\dot{\pi} \pi \circ \mu \circ \eta \tilde{n}$ dan $\zeta \eta \tau \varepsilon \dot{\varepsilon} \omega$ Kedua kata tersebut diawali dengan kata êpyou. Kata ini tidak hanya menunjukkan perbuatan partikular tetapi menekankan hasil perbuatan dari seluruh hidup seseorang. ${ }^{41}$ Ketekunan adalah sikap dan cara hidup untuk tetap

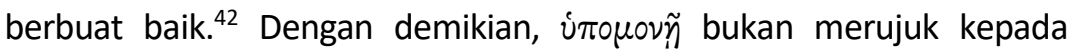
kesempurnaan perbuatan (tanpa dosa) melainkan motivasi hati yang

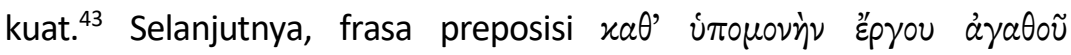

38. VanLandingham, Judgment and Justification, 220.

39. VanLandingham, Judgment and Justification, 222.

40. Yinger, Judgment According to Deeds, 157.

41. Sanday and Arthur, Romans, 57.

42. Hauck, "u்rouovñ." TDNT 4 (1967), 582.

43. Ada dua pendapat arti kata únouovñ, yaitu sebagai ketekunan tetapi tidak dikaitkan dengan kesabaran (Jewett, Romans, 204; Murray, Romans, 64; Käsemann, Romans, 60) dan kesabaran di dalam bertekun (Yinger, Judgment 
menjelaskan cara seseorang گท $\tau^{\varepsilon} \omega$ kemuliaan, hormat dan ketidakbinasaan. Kata $\eta^{\prime} \varepsilon \dot{\varepsilon} \omega$ seringkali digunakan dalam konteks moral

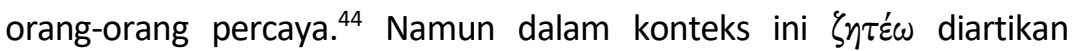
sebagai mempertahankan daripada mencapai tujuan. ${ }^{45}$ Di samping itu,

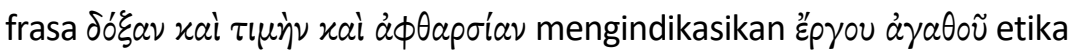

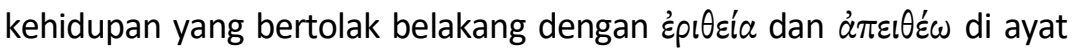

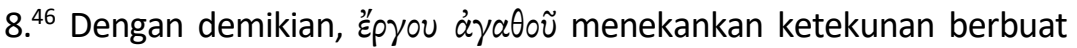

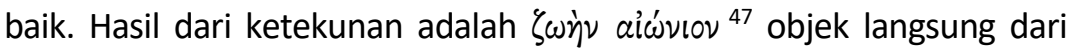
$\dot{\alpha} \pi 0 \delta i \delta \delta \omega \mu$ Tuhan di ayat $6 .{ }^{48}$ Jadi tekun berbuat baik bukanlah untuk mendapatkan keselamatan, tetapi untuk memperlihatkan hasil yang didapatkan atau ganjaran Ilahi, dan mengkontraskannya dengan perbuatan jahat. ${ }^{49}$

According to Deeds, 159; Dunn, Romans 1-8, 85; Fitzmyer, Romans, 303; Cranfield, Romans vol. 1, 147). Dalam hal ini, penulis lebih setuju mengartikan úrouovñ dengan ketekunan sebagai bentuk konsisten di dalam berbuat baik.

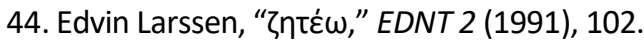

45. Dunn, Romans 1-8, 86.

46. Bdk. Godet, Romans, 119-20; Leon Morris, The Epistle to the Romans (The Pillar New Testament Commentary (Leicester: Apollos, 1988), 116-17; Dunn, Romans 1-8, 86. Namun Jewett (Romans, 205) tidak setuju jika

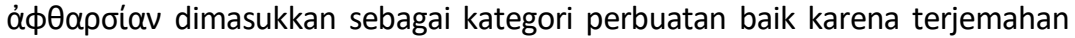

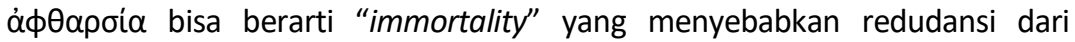
"kehidupan kekal."

47. Konsep ini ada di dalam Yudaisme (Dan. 12:2; 2Mak. 7:9; 4Mak. 15:3; 1QS 4:7) dan juga Perjanjian Baru (Mrk. 10:17; Luk. 10:25; Yoh. 3:15-16; Kis. 13:46, 48; 1Yoh. 1:2; 2:25; Yud. 21; Rm. 5:21; 6:22-23; Gal. 6:8; 1Tim. 1:16; 6:12; Tit. 1:2; 3:7). Dunn, Romans 1-8, 85.

48. Cranfield, Romans vol. 1, 147.

49. Cranfield, Romans vol. 1, 153. 
Jika ayat 7 menekankan perbuatan yang berorientasi mencari

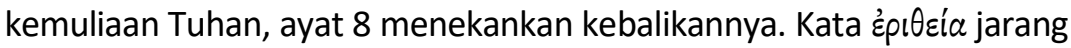
dipakai di dalam literatur Yunani, ${ }^{50}$ tetapi muncul 5 kali di surat-surat Paulus (lih. Rm. 2:8; 2Kor. 12:20; Gal. 5:20; Flp. 1:17; 2:3). Dalam Roma 2:6-11, kata ini menekankan sikap mementingkan diri sendiri yang

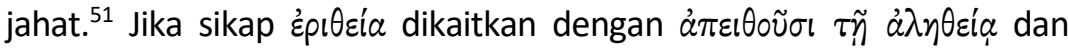

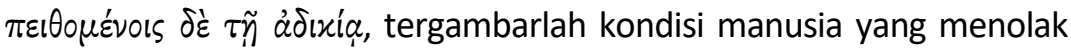

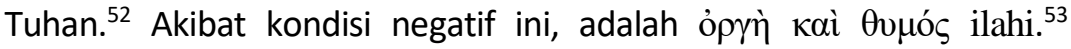
Walaupun kata $\theta \varepsilon o ́ s ~ t i d a k ~ m u n c u l$, para pembaca akan mengetahui bahwa keduanya merujuk kepada emosi ilahi. Dunn menyebutnya sebagai "impassibility of God" ${ }^{54}$ yang memperlihatkan batas akhir dari kesempatan untuk bertobat. Ini juga menekankan Tuhan akan mengeksekusi penghukuman-Nya.

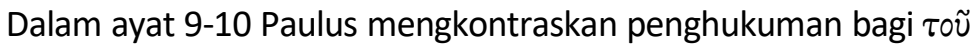

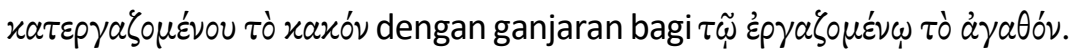
Formula antitesis ini terjadi di penghakiman eskatologis. Penggunaan kata $\theta \lambda \tilde{\imath} \psi ı$ dan $\sigma \tau \varepsilon \nu 0 \chi \omega$ pía secara bersamaan memperlihatkan efek kuat

50. Dunn, Romans 1-8, 86.

51. Jewett, Romans, 206.

52. Dunn, Romans 1-8, 87.

53. Cranfield, Romans vol. 1, 149, berpendapat penggunaan ovrgh. kai. qumo,j secara bersamaan dapat dimengerti sebagai sinonim, yaitu kata yang kedua memberikan efek yang kuat dan menekankan kata yang pertama.

54. Dunn, Romans 1-8, 87. 
murka Tuhan di dalam penghukuman eskatologis. ${ }^{55}$ Deskripsi Paulus

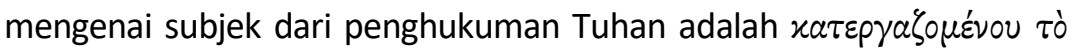

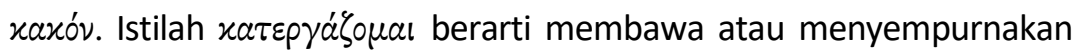

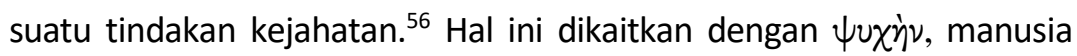
yang seharusnya hidupnya merefleksikan Penciptanya, ternyata berorientasi kepada kejahatan, ${ }^{57}$ dan berakibat penghukuman. Di sisi yang lain, orang yang berbuat baik akan diganjar oleh Allah dengan $\delta o ́ \xi \alpha$,

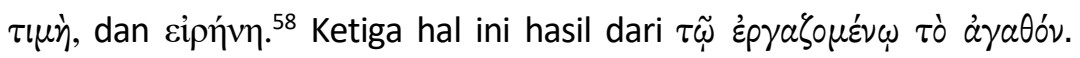

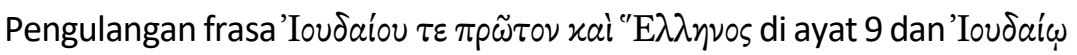
$\tau \varepsilon \pi \rho \tilde{\omega} \tau o \nu$ xal "E $\mathrm{A} \lambda \eta \nu \iota$ di ayat 10 (bdk. Rm. 1:16) untuk mengkritik keistimewaan orang Yahudi bahwa mereka sejajar dengan bangsa lain di dalam penghakiman Tuhan.

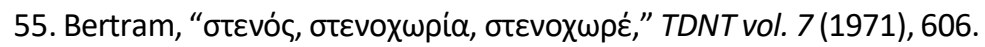
Formula ini juga ada di LXX (Ul. 28:53, 55, 57; Est. 1:1; Yes. 8:22; 30:6) dan juga di Roma 8:35 dan 2 Korintus 6:4 yang menekankan murka ilahi. Jewett, Romans, 217.

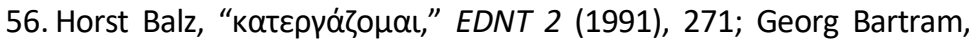
"katerga,zomai," TDNT 3 (1965), 635.

57. Fitzmyer, Romans, 302, menggambarkan bahwa hati termasuk bagian manusia yang terkena dampak penghukuman.

58. Kata eipńvn merefleksikan dua pengertian. Pertama, jika disejajarkan dengan Roma 2:7 Eipŕvn untuk menggambarkan keadaan individu yang berbuat baik di pengadilan eskatologis. Dunn, Romans 1-8, 88. Kedua, secara implisit cipńvn dapat dikaitkan dengan keselamatan. Hal ini dapat dibandingkan dengan Roma 1:7. Werner Foerster, "zipńvn." TDNT 2 (1964) 407-408; Jewett, Romans, 207-08; Cranfield, Romans vol. 1, 150, berpendapat bahwa eipńvn sama dengan keselamatan. 


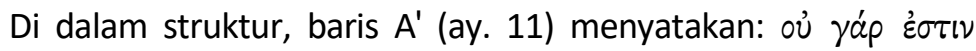

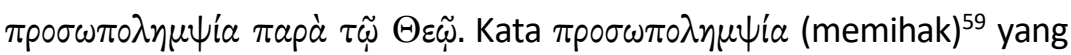
dihubungkan dengan negasi oủ memperlihatkan koreksi teologis yang dianut orang Yahudi. ${ }^{60}$ Di akhir zaman Tuhan tidak akan berpihak kepada siapapun. ${ }^{61}$

\section{Hari Penghakiman Kristus}

Roma 6:12-16 membicarakan tentang kepemilikan hukum Taurat dan eskatologis penghakiman Kristus. $^{62}$ Paulus memahami penghakiman berdasarkan perbuatan tidak terlepas dari Injil dan Kristus. Fokus utama bagian ini adalah bagaimana Paulus secara implisit memunculkan Injil di dalam pengadilan eskatologis dan Kristus sebagai

59. Kata ini sering dipakai di Perjanjian Lama maupun di tulisan Yudaisme (UI. 10:17; 2Raj. 3:14; 2Taw. 19:7; Mal. 1:8; Ay. 34:19; 42:8; Mzm. 82:2; Sir. 35:12-13; Ps. Sol. 2:18; Jub. 5:15; Gal. 2:6; Kol. 3:25; Ef. 6:9), dan juga dipakai untuk memberikan salam penghormatan dengan membungkukkan kepala kepada seseorang. Fitzmyer, Romans, 303.

60. Fitzmyer, Romans, 303.

61. Elliott, The Rhetoric of Romans, 122; Jouette M. Bassler, Divine Impartiality: Paul and A Theological Axiom, SBL 59 (Chico: Scholars Press, 1982), 137.

62. Beberapa ahli berpendapat bahwa Roma 2:12-16 bukan lanjutan dari Roma 2:1-11 melainkan bagian dari 2:17-29 karena topik pembicaraan Paulus yang berkesinambungan mengenai Taurat dan sunat (Käsemann, Romans, 6162; Dunn, Romans 1-8, 94-95; Fitzmyer, Romans, 305). Namun penulis setuju Roma 2:12-16 bagian dari Roma 2:1-11 karena topik kepemilikan Taurat menjadi sorotan Paulus yang dikaitkan dengan ketidakberpihakan Allah hingga di penghakiman. Ayat 16 merupakan inklusio penghakiman eskatologis di ayat 1-5 (Moo, Romans, 144; Godet, Romans, 121; Murray, Romans, 68-69; Jewett, Romans, 210; Cranfield, Romans vol. 1, 153). 
hakim. Baik memiliki atau pun tidak memiliki Taurat, orang tidak dapat menghindari penghakiman Tuhan dan menyembunyikan perbuatan jahatnya.

Dalam surat Roma kata vópos muncul untuk pertama kalinya di sini (ay. 12), dan merujuk kepada hukum Yahudi yang dikenal sebagai pemilik Taurat. Paulus menyatakan bahwa kepemilikan Taurat bukan jaminan untuk terhindar dari penghukuman ilahi, ${ }^{63}$ karena kedudukan yang sama di dalam pengadilan Tuhan. ${ }^{64}$ Kata à $\pi \dot{\lambda} \lambda \lambda u \mu ı$ menunjukkan akibat dari perbuatan dosa (bdn. 1Kor. 1:18; 15:18; 2Kor. 2:15; 4:3; 2 Tes. 2:10; Yoh. 3:16; 10:28; 17:28). Mereka memiliki Taurat akan dihakimi

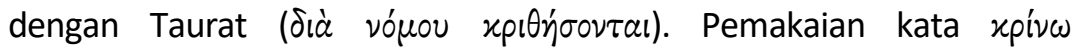
menekankan Allah sendiri yang akan menghakimi dan menghukum orang yang memberontak terhadap Taurat. ${ }^{65}$

Muncul satu permasalahan di ayat 13 , yaitu Paulus seolah-olah menyatakan pembenaran karena melakukan Taurat. Paulus menggaungkan ảxpoatai vómou agar lawan bicaranya (orang Yahudi), yang memperhatikan shema (UI. 6:4), menyadari ada perbedaan antara mendengar Taurat dan melakukan Taurat ${ }^{66}$ karena berkaitan dengan

63. Dunn, Romans 1-8, 104. Käsemann, Romans, 61.

64. Philip F. Esler, Conflict and Identity in Romans: the Social Setting of Paul's Letter (Minneapolis: Fortress, 2003), 152.

65. Volkmar Herntrich, "kri,nw ktl.," TDNT 3 (1965), 924.

66 . Dunn berpendapat antara mendengar dan melakukan hukum Taurat terdapat " $a$ wedge between the interconnected elements of Jewish selfunderstanding." Dunn, Romans 1-8, 97. 
status dibenarkan di pengadilan Tuhan. ${ }^{67}$ Paulus berargumentasi bahwa mendengar Taurat perlu ditindaklanjuti dengan melakukan Taurat, tanpa itu akan dikategorikan sebagai orang yang berbuat jahat atau

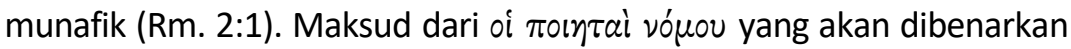
di penghakiman terakhir ${ }^{68}$ adalah orang yang mendengar dan melakukan Taurat secara konsisten sampai akhir. ${ }^{69}$ Dengan demikian, Paulus tidak menjadikan Taurat sebagai pembenaran di pengadilan akhir.

Pada ayat 14 Paulus membangun argumentasinya terhadap lawan bicaranya mengenai non-Yahudi yang tidak memiliki Taurat tetapi melakukan Taurat. Paulus berpendapat mereka memiliki Taurat melalui

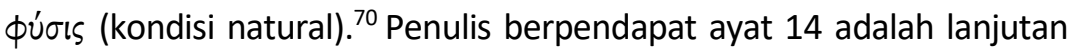
kritikan Paulus kepada lawan bicaranya mengenai hak istimewa,

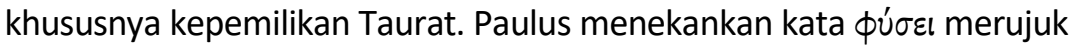

67. Stanley K. Stowers, A Reading of Romans: Justice, Jews, and Gentiles (New Haven: Yale University Press, 1994), 140, berpendapat, "Instead, Paul makes a distinction basic to the religion of Judaism: the wicked, who make no serious attempt to follow God's law, and those who live, though imperfectly, within its teachings."

68. Wright ("The Law in Romans 2," 146) berpendapat ayat 13 dan 14 berkaitan dengan pembenaran akhir.

69. Moo, Romans, 147. Bdk. Dunn, Romans 1-8, 97-98.

70. Beberapa ahli berbeda pendapat untuk menafsirkan bagian ini. Jewett membagi dalam beberapa pendapat, yaitu: (a) Paulus ingin mengonfirmasi akuntabilitas mereka ketika mereka dihukum di penghakiman akhir; (b) Paulus ingin menunjukkan adanya kebenaran di dalam nonYahudi meskipun tidak memiliki Injil tetapi mereka dibenarkan di pengadilan akhir; (c) Paulus memperlihatkan prakristen bukan Yahudi dengan mengonfirmasi bahwa hukum Tuhan sudah ada meskipun di dalam hati mereka. Jewett, Romans, 21213. 
kepada orang yang tidak memiliki hukum Taurat tetapi melakukan Taurat secara alamiah. ${ }^{71}$ Dengan kata lain, kepemilikan Taurat bukanlah berdasarkan tanda lahir melainkan perbuatan mentaati Taurat, karena Taurat bersifat inklusif. ${ }^{72}$

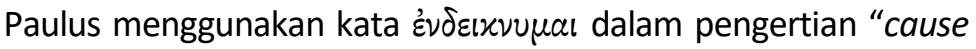
something to become known, show, demonstrate."73 Apa yang

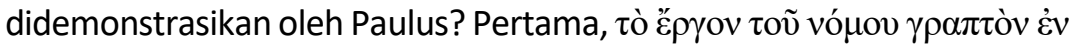

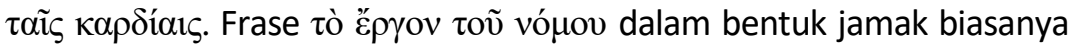
dipakai oleh Paulus dalam nuansa negatif (Rm. 3:20, 28; Gal. 2:16; 3:2, $5,10) .{ }^{74}$ Namun pada bagian ini, menekankan perbuatan Taurat yang keluar dari dalam hati. ${ }^{75}$ Penggunaan dari kata ypa $\tau \tau$ ós menunjukkan kekuatan moral berasal dari Tuhan dan bukan dari hal yang lainnya. ${ }^{76}$

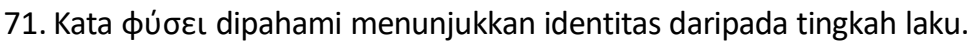
Banyak para ahli yang berpendapat фúocı adalah orang non-Yahudi sebab jika non-Yahudi Kristen maka rujukan Paulus adalah bukan berdasarkan natural melainkan anugerah (Wright, "The Law in Romans 2," 131-50; Simon J. Gathercole, "A Law unto Themselves: The Gentiles in Romans 2.14-15 Revisited." Journal for Study of the New Testament 85 [Maret 2002]:27-49; Dunn, Romans 1-8, 98; Fitzmyer, Romans, 310; Moo, Romans, 150).

72. Hultgren, Romans, 118. Bdk. Wright, "The Law in Romans 2," 146; Dunn, Romans 1-8, 105; Heikki Räisäne, Paul and the Law (Fortress: Philadelphia, 1986), 103.

73. A Greek-English Lexicon of the New Testament and Other Early

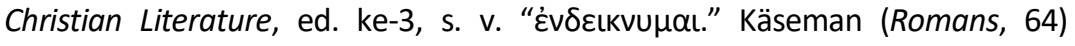
menyebutnya, "concrete act demanded by the law."

74. Dunn, Romans 1-8, 100.

75. Käsemann menyebutnya, "concrete act demand by the law."Käsemann, Romans, 64.

76. Jeffery S. Lamp, "Paul, the Law, Jews, and Gentiles: A Contextual and Exegetical Reading of Romans 2:12-16." Journal of The Evangelical Theological Society 42 (1999): 47. 


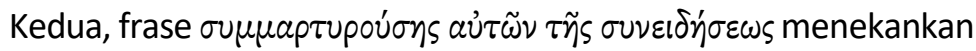
kesadaran moral seseorang. Kata $\sigma u v \varepsilon i \delta \eta \sigma \varsigma^{77}$ memperlihatkan kesadaran di dalam hati manusia mengenai pelanggaran. ${ }^{78}$ Ini dikaitkan

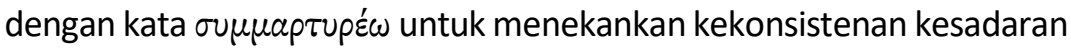
norma seseorang. ${ }^{79}$ Kemudian hal ini dilanjutkan dengan penjelasan

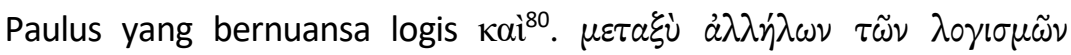

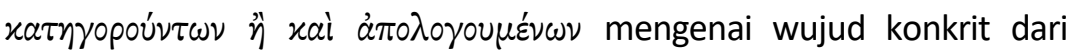

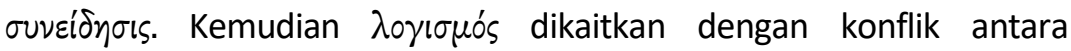

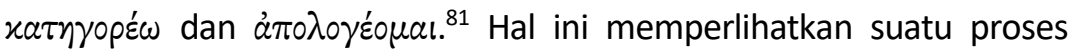
kritik diri sendiri supaya dapat melakukan perbuatan yang benar..$^{82} \mathrm{Jika}$ non-Yahudi mampu melakukan kritik diri tanpa Taurat, maka orang

77. Muncul 14 kali di dalam surat-surat Paulus Roma 2:15; 9:1; 13:5; 1Kor. 8:7, 10, 12; 10:26, 27, 28, 29 (2x); 2Kor. 1:12; 4:2; 5:11. Hultgren, Romans, 118.

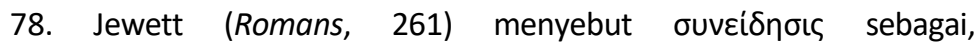
"anthropological phenomenon of the knowledge one has "with oneself" that "marks any transgression against the individual's accepted code."'"

79. Jewett, Romans, 261.

80. Kata kai menunjukkan konotasi yang menjelaskan klausa sebelumnya. A Greek-English Lexicon of the New Testament and Other Early

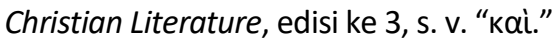

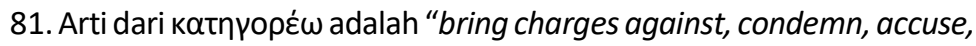
reproach." A Greek-English Lexicon of the New Testament and Other Early

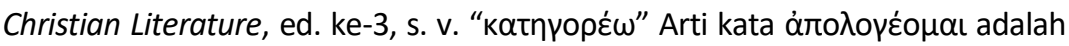
"speak in one's defense, defend oneself." A Greek-English Lexicon of the New

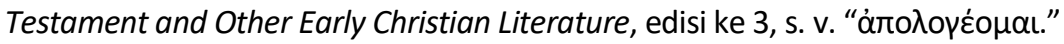

82. Käsemann (Romans, 66) mengatakan, "that such self-criticism anticipates the last judgment." 
Yahudi yang memiliki Taurat harus lebih mampu melakukan kritik terhadap perbuatannya.

Akhirnya Paulus membahas Sang Hakim di pengadilan akhir zaman di ayat $16 .^{83}$ Di sini, untuk pertama kalinya nuansa injil dihadirkan

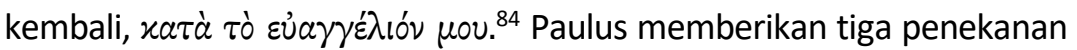

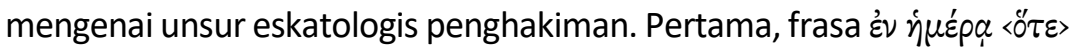
xpíveı ó @eòs jelas merujuk kepada hari YHWH (lihat ayat 5). Walaupun

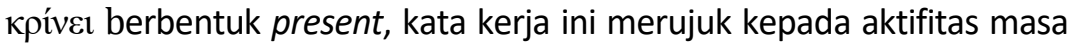
depan (the futuristic present). ${ }^{85}$ Ini menunjukkan adanya kelanjutan antara penghakiman masa sekarang (Rm. 2:13) dengan murka Tuhan di

83. Jika dilihat topiknya ayat 16 tidak tersambung dengan bagian sebelumnya karena Paulus tidak memakai kata penghubung. Berbagai pendapat dilontarkan. Fitzmyer berpendapat penempatan ayat 16 secara logis adalah setelah ayat 13 (Fitzmyer, Romans, 311). Käsemann berpandangan adanya kontradiksi mengenai hari penghakiman di ayat 16 sehingga lebih tepatnya diletakkan setelah 14 (Käsemann, Romans, 67). Dalam hal ini, penulis berpendapat ayat 16 merupakan kesimpulan akhir Paulus mengenai penghakiman eskatologis (bdk. ay. 5) berdasarkan perbuatan dan untuk semua manusia, tanpa terkecuali (ay. 6-14).

84. K. L. Snodgrass, "Justification by Grace - to the Doers: An Analysis of the Place of Romans 2 in the Theology of Paul" NTS 32 (Januari, 1986): 79.

85. Memang kata кpíveı menimbulkan perbedaan di dalam naskah. Beberapa naskah (seperti B2, $\Psi, 6,1241$ ) menyatakan кpiveı dalam bentuk present. Sementara beberapa naskah (D2, 33, 1739, 1881, Majority text, latt, co) lainnya menyatakan крıvei dalam bentuk future. Dalam hal ini, penulis setuju dengan Schreiner yang mengatakan, "Paul probably intended a present-tense verb, but the reference is to the final judgment." Schreiner, Romans , 126. Menurut Friedrich Blass, Albert Debrunner, Robert Walter Funk (A Greek Grammar of the New Testament and Other Early Christian Literature [Chicago: University of Chicago Press, 1961], 168) mengatakan adanya penggunaan bentuk present tetapi mengindikasikan future." 
masa yang akan datang (Rm. 1:18; 2:5, 8). ${ }^{86}$ Selanjutnya, pandangan

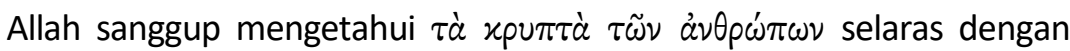
pemahaman kuasa Allah di dalam Perjanjian Lama. ${ }^{87} \mathrm{Hal}$ ini untuk menekankan di dalam pengadilan Tuhan tidak ada seorangpun yang dapat menyembunyikan kejahatannya (Rm. 2:1, 3).

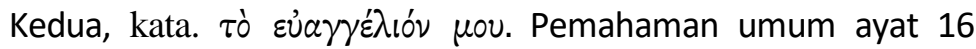
adalah "hari penghakiman Tuhan tiba, sesuai dengan Injil yang kuberitakan, akan menghakimi segala sesuatu yang tersembunyi dalam hati manusia melalui Kristus Yesus." ${ }^{18}$ Namun ada yang menafsirkan, "pada hari penghakiman tiba, Tuhan akan menghakimi segala sesuatu yang tersembunyi dalam hati manusia menurut Injilku melalui Kristus

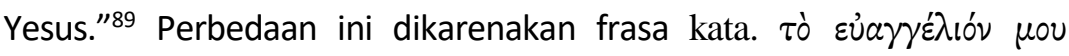
dimengerti Tuhan menghakimi berdasarkan Injil Paulus, bukan Injil Kristus. Penulis lebih setuju dengan penafsiran kedua. Mengenai kata $\tau \dot{o}$

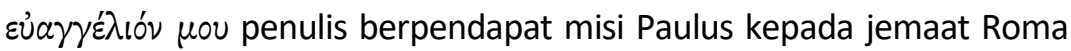

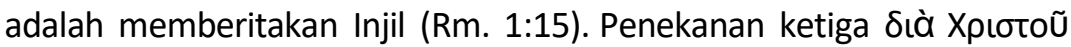

86. Dunn, Romans, 102. Jewett (Romans, 218) berpendapat, "It is perhaps for this reason that hémera ("day") appears here as in 2:5 without the article, referring to God's judgment that can occur at any time, in the present as well as in the final judgment."

87. Daniel 2:22; Sirakh 39:19; Yeremia 16:17; 23:24; Ayub 34:22. Jewett, Romans, 217. Albrecht Oepke and Rudolf Meyer ("крuлtw.," TDNT 3 (1965),

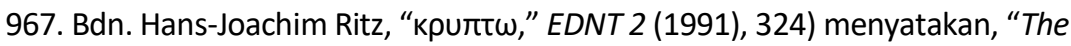
OT takes God's omnipresence and omniscience more seriously that any religion."

88. Fitzmyer, Romans, 305; TB-LAl, NRSV, NIV; Morris, Romans. 114; Moo, Romans, 144; Cranfield, Romans Vol. 1, 136.

89. Dunn, Romans 1-8, 94. 
'Inбoũ, yaitu Kristus sebagai hakim di pengadilan akhir (bdk. Kis. 10:42; 1Kor. 4:4; 2Kor. 5:10). ${ }^{90}$

\section{Kesimpulan}

Paulus memakai isu fundamental dari "Penghakiman menurut perbuatan" yang berakar dari Yudaisme Bait Allah Kedua untuk meyakinkan lawan bicaranya bahwa semua orang akan dihakimi berdasarkan perbuatan di pengadilan akhir Tuhan. Eskatologi pengadilan Tuhan ini bukan untuk mendapatkan keselamatan. Hal ini selaras dengan tesis Paulus di Roma 1:16-17 bahwa Injil Kristus yang dapat menyelamatkan manusia. Perbuatan di dalam kerangka eskatologi penghakiman adalah untuk menunjukkan keselarasan antara iman kepada Tuhan dan perbuatan di dalam kehidupan. Oleh sebab itu, ganjaran dari penghakiman Tuhan adalah penghukuman kepada yang melakukan perbuatan jahat dan bagi mereka yang setia akan terhindar dari penghukuman.

Apakah penghakiman berdasarkan perbuatan bertentangan dengan pembenaran berdasarkan iman (Rm. 3:20)? Menurut penulis, Roma 2:1-16 tidak berbicara mengenai keselamatan. Paulus sedang menekankan perbuatan yang selaras dengan iman kepada Tuhan. Perbuatan merupakan satu kesatuan yang utuh dengan iman. ${ }^{91} \mathrm{Hal}$ ini

90. Jewettt, Romans, 218. Bdn. Colin G. Kruse, Paul's Letter to the Romans, PNTC (Grand Rapids: Eerdmans, 2012), 34; Fitzmyer, Romans, 312.

91. VanLandingham menyebutnya, "obedience that springs from faith." VanLandingham, Judgment and Justification, 232. Begitu juga dengan Yinger yang mengatakan, "It is the standard Jewish expectation that one's outward 
dapat dilihat dari argumentasi Paulus mengenai melakukan Taurat bukan berdasarkan kepemilikan namun berdasarkan mendengar (iman) dan melakukan (perbuatan) yang sejajar (Rm. 2:13). Oleh karena itu, Paulus tetap menekankan iman kepada Tuhan yang menentukan keselamatan dan perbuatan mencerminkan iman tersebut. Dengan demikian, Paulus menggarisbawahi iman dan perbuatan menjadi satu kesatuan yang penting di dalam keselamatan.

\section{Daftar Pustaka}

\section{Buku}

Bassler, J. M. Divine Impartiality: Paul and Theological Axiom. Society of Biblical Literature 59. Chico: Scholars, 1982.

Bird, Michael F. A Bird's-Eye View of Paul: The man, his mission, and his message. Nottingham: Inter Varsity, 2008.

Blass, Friedrich, Albert Debrunner, Robert Walter Funk, A Greek Grammar of the New Testament and Other Early Christian Literature. Chicago: University of Chicago Press, 1961.

Cranfield, C. E. B. A. A Critical and Exegetical Commentary on the Epistle to the Romans Vol. 1. International Critical Commentary. New York : T\&T Clark, 2004.

Dunn, James D. G. Romans 1-8. Word Biblical Commentary vol. 38a. Nashville: Nelson, 1988.

Ellis, Edward E. Paul's Use of the Old Testament. London: Oliver and Boyd, 1957.

Esler, Philip F. Conflict and Identity in Romans: the Social Setting of Paul's Letter. Minneapolis: Fortress, 2003.

Fitzmyer, Joseph A. Romans: A New Translation with Introduction and Commentary. The Anchor Bible. New York: Doubleday, 1993.

Godet, Frederic L. Commentary on Romans. Grand Rapids: Kregel, 1977. Hultgren, Arland J. Paul's Letter to the Romans: a Commentary. Grand Rapids: Eerdmans, 2011.

behavior (one's work of way) will correspond to, and be a visible manifestation of, inward reality." Yinger, Judgment According to deeds, 181. 
Jewett, Robert. Romans: A Commentary. Hermeneia. Minneapolis: Fortress, 2007.

Käsemann, Ernst. Commentary on Romans. Grand Rapids: Eerdmans, 1980.

Kruse, Colin G. Paul's Letter to the Romans. PNTC. Grand Rapids: Eerdmans, 2012.

Linebaugh, Jonathan A. God, Grace, and Righteousness in Wisdom of oalomon and Paul's Letter to the Romans. Boston: Brill, 2013.

Moo, Douglas. The Epistle to the Romans. The New International Commentary on the New Testament. Diedit oleh Gordon D. Fee. Grand Rapids: Eerdmans, 1996.

Morris, Leon. The Epistle to the Romans. The Pillar New Testament Commentary. Leicester: Apollos, 1988.

Murray, John. The Epistle to the Romans. New International Commentary on the New Testament. Grand Rapids: Eerdmans, 1987.

Osborne, Grandt R. Romans. Illinois: InterVarsity, 2004.

Räisäne, Heikki. Paul and the Law. Fortress: Philadelphia, 1986.

Sanday, W. and A. C. Headlam. A Critical and Exegetical Commentary on the Epistle to the Romans. International Critical Commentary. Edinburg: T\&T Clark, 1980.

Sanders, E. P. Paul, The Law, and The Jewish People. Minneapolis: Fortress, 1983. . Paul and Palestinian Judaism: a Comparison of Patterns of Religion. Minneapolis: Fortress, 1977.

Schreiner, Thomas R. Romans. Baker Exegetical Commentary on the New Testament. Grand Rapids: Baker, 1998. . The Law and Its Fulfillment: A Pauline Theology of Law. Baker Books: Grand Rapids, 1993.

Stowers, Stanley K. A Reading of Romans: Justice, Jews, and Gentiles. New Haven: Yale University Press, 1994.

VanLandingham, Chris. Judgment \& Justification in Early Judaism and the Apostle Paul. Peabody: Hendrickson, 2006.

Watson, Francis. Paul, Judaism, and the Gentiles: Beyond the New Perspective. Grand Rapids: Eerdmans, 2007.

Wright, N. T. "The Law in Romans 2." Dalam Paul and the Mosaic Law, Diedit oleh James D. G. Dunn. Tübingen: Mohr, 1996. 
. "The New Perspective on Paul (2003)." Dalam Pauline Perspective: Essays on Paul, 1978-2013. Minneapolis: Fortress, 2013.

. Paul: Fresh Perspectives. London: SPCK, 2005. . What St. Paul Really Said. Oxford: Lion, 1997.

Yinger, Kent L. Paul, Judaism, and Judgment According to Deeds. Society for New Testament Studies 105. Cambridge: Cambridge University, 1999.

\section{Jurnal}

Gathercole, Simon J. "A Law unto Themselves: The Gentiles in Romans 2.14-15 Revisited." Journal for Study of the New Testament 85 (March 2002): 27-49.

Lamp, Jeffrey S. "Paul, the Law, Jews, and Gentiles: A Contextual and Exegetical Reading of Romans 2:12-16." Journal of The Evangelical Theological Society 42 (1999): 37-51.

Snodgrass, K. L. "Justification by Grace-to the Doers: An Analysis of the Place of Romans 2 in the Theology of Paul." New Testament Studies 32 (January, 1986): 72-93.

\section{Kamus}

Balz, Horst Robert and Gerhard Schneider. Exegetical Dictionary of New Testament Vol. 2. Grand Rapids: Eerdmans, 1991.

Danker, Frederick William and Walter Bauer. ed. A Greek-English Lexicon of the New Testament and Other Early Christian Literature. Chicago: University Chicago Press, 2000.

Kittel, Gerhard and Geoffrey W. Bromiley. Theological Dictionary of New Testament Vol. 2. Grand Rapids: Erdmans, 1964.

. Theological Dictionary of New Testament Vol. 3. Grand Rapids: Erdmans, 1965.

.Theological Dictionary of New Testament Vol. 4. Grand Rapids: Erdmans, 1967.

. Theological Dictionary of New Testament Vol. 7. Grand Rapids: Erdmans, 1971. 